\title{
Foreign Aid Inflow and Domestic Savings in Uganda: Error Correction Modelling
}

\author{
Henry Tumwebaze Karamuriro ${ }^{1}$, Edward Patrick Ssemanda ${ }^{1}$, Edward Bbaale ${ }^{2}$ \\ ${ }^{1}$ Department of Economics and Statistics, Kyambogo University, Kampala, Uganda \\ ${ }^{2}$ School of Economics, Makerere University, Kampala, Uganda
}

Email address:

htumwebaze@yahoo.com (H. T. Karamuriro), ssemandapatrick@yahoo.com (E. P. Ssemanda), eddybbale@gmail.com (E. Bbaale)

To cite this article:

Henry Tumwebaze Karamuriro, Edward Patrick Ssemanda, Edward Bbaale. Foreign Aid Inflow and Domestic Savings in Uganda: Error Correction Modelling. Journal of World Economic Research. Vol. 9, No. 1, 2020, pp. 41-50. doi: 10.11648/j.jwer.20200901.17

Received: June 13, 2019; Accepted: July 23, 2019; Published: January 27, 2020

\begin{abstract}
The study sought to establish the impact of foreign aid inflow on domestic savings in Uganda. It was motivated by the low savings ratio which was identified as one of the major constraints to future growth in Uganda, under Vision 2025. Error-Correction Modelling was applied on a time series database for the period 1970-2016. Results of the study show that foreign aid has a negative impact on domestic savings in Uganda both in the short-run and long-run. An increase in foreign aid inflow by $1 \%$ of GDP leads to $0.71 \%$ decrease in gross domestic savings in the long-run. This implies that an increase in foreign aid as a whole crowded-out domestic savings in the short-run and long-run. By making resources easily available, foreign aid encourages relaxation in saving effort and increases consumption. A policy implication of this result is that Uganda should be wary in soliciting for foreign aid. If foreign aid becomes expedient, then it should be channeled to productive ventures.
\end{abstract}

Keywords: Foreign Aid, Domestic Savings, Error Correction Modelling

\section{Introduction}

One of the major economic problems of developing countries is inadequate domestic savings. In economic development literature, saving is the traditional source for investment and, therefore, a determinant of capital formation and economic growth [30]. This study contends that the extent to which the level of savings can affect capital formation and economic growth largely depends on the capacity of the economy to channel the savings into productive use. The Harrod-Domar growth model also posits that saving provides the funds which are borrowed for investment purposes. The model suggests that an economy's rate of growth depends on the level of domestic savings, the savings ratio and the productivity of investment. Therefore, to accelerate the rate of capital formation through investment, the level of domestic savings has to be increased high enough to fund investment. In developing economies where the level of domestic savings is low, foreign aid can be used to supplement domestic savings to foster investment and economic growth. This explains why foreign aid to developing countries has gained significant importance over the past half a century.

The early view about the role of foreign aid in economic development is contained in the take-off hypothesis postulated by Rostow [36]. Rostow suggested that developing countries lack sufficient domestic savings to finance investment requirements and therefore, foreign aid would act as a complement to help them take-off into selfsustaining growth. According to this hypothesis, domestic savings during the take-off stage could be supplemented by foreign aid inflow so as to increase the level of investment required to spur economic growth. Rostow argued that foreign aid is an important source of foreign savings for developing countries which augments their domestic resources available for investment.

Rostow's view was reinforced by the two gap model propounded by Chenery and Strout [7]. The model is based on the premise that developing countries lack sufficient domestic savings to finance investment requirements. The difference between the required investment and available amount of domestic savings yields the investment-savings gap. At the same time, developing countries are relatively 
less endowed with capital goods which have to be imported. Yet, they mainly depend on primary commodity exports which fetch low prices on international markets. The difference between the values of imports and exports yields the foreign exchange gap. If the required level of investment is to be realized, external finance must be sufficient to fill the two gaps. The basis of the two gap model, therefore, is that foreign aid supplements domestic savings and foreign exchange shortages [32]. Other studies have also found a positive effect of foreign aid on domestic savings and economic growth through the importation of technology, managerial skills and market access [21].

However, these views were challenged by Griffin [14] and Griffin and Enos [15] who argue that foreign aid inflow would displace domestic savings and, thus, act as a substitute rather than a complement. These authors advanced a number of persuasive theoretical reasons to explain why foreign aid could have a negative impact on the domestic intentions to save. One reason that has been advanced to support this argument is that most foreign aid goes into consumption, and thus crowds out domestic savings and investment. According to this view, foreign aid inflow represents an addition to the total supply of resources available to a country and thereby increases the possible magnitude of domestic expenditures. Secondly, if foreign aid causes the exchange rate to appreciate, exports will be affected and this would lead to a reduction in domestic savings, a phenomenon known as the "Dutch disease" [42]. This is particularly prevalent in countries where foreign aid plays an important role in covering the external deficit. In both cases, foreign aid would have a detrimental effect on domestic saving efforts.

The view that foreign aid displaces domestic savings could be used to explain why most developing countries have had little or no development in spite of the substantial amounts of foreign aid received over the last half a century. Almost all Sub-Saharan African countries are still characterized by high levels of poverty, indebtedness, fiscal deficits, unemployment, income inequalities and poor economic performance despite the high foreign aid inflows [20]. According to the World Bank [45], the Sub-Saharan African region is still experiencing negative per capita income growth, weak investment, and a decline in productivity growth. This scenario has prompted aid donor agencies and economic analysts to revisit the earlier views on the effectiveness of foreign aid. One of the central perspectives in aid effectiveness is the impact of foreign aid on domestic savings.

Uganda's domestic savings to GDP ratio has averaged only 7.8 per cent through the period 1970-2016, which is relatively low compared with other developing countries. For example, Kenya's domestic savings to GDP ratio was 15.4 per cent during the same period [44]. The low level of domestic savings in Uganda has led to dependence on foreign aid as an alternative source of resources to promote investment and economic growth. Hence, Uganda has been one of the top recipients of donor aid during the past three decades. Between 1970 and 2016, the country received more than $\$ 40$ billion in Official Development Assistance (ODA), ranking it as the 13th largest aid-recipient country worldwide [44]. The ratio of aid-to-GDP peaked at $19 \%$ in 1992 , and has remained around $10 \%$ over the last three decades. Therefore, understanding the nexus between foreign aid inflow and domestic savings in Uganda is important in order to be able to formulate appropriate policies for promoting investments and economic growth of the country.

The effect of foreign aid on domestic savings in Uganda has not been clear; whether foreign aid promotes domestic savings or substitutes for it. The absence of a systematic analysis to evaluate the role of foreign aid on domestic savings in Uganda stands out as one of the major deficiencies in the policy-related literature. Therefore, the objective of this paper is to test empirically the impact of foreign aid inflow on the level of domestic savings in Uganda. The rest of the paper is organized as follows: section 2 presents the theoretical and empirical literature, section 3 discusses methodology and data analysis, empirical results of the study are explained in section 4. Finally, summary and policy implications are drawn in section 5.

\section{Theoretical and Empirical Literature}

Theoretical literature shows that there is no consensus on the impact of foreign aid inflow on domestic savings. While some studies have suggested that foreign aid inflow complements domestic savings [7, 40], other studies have proposed that foreign aid inflow substitutes domestic savings $[6,17]$. In one of the early studies, Chenery and Strout [7] provided a detailed theoretical exposition of the manner in which foreign aid could complement domestic savings in developing countries. According to this study, foreign aid could enhance the growth potential of these countries by augmenting the domestically available savings. The study indicates that the low levels of domestic savings act as constraints on the investment activity, and consequently on the desired levels of economic growth. With foreign aid removing the limits on domestic savings, developing countries can launch into a path that would eventually result in self-sustaining growth.

Taslim and Weliwita [40] traced the theoretical relationship between foreign aid inflow and domestic savings to both the vicious circle of poverty theory and the two-gap theory by Chenery and Strout [7]. The vicious circle of poverty theory holds that poverty is both a cause and a consequence of poverty. Poor countries with limited capital stock can save little as their incomes are barely enough to ensure subsistence needs. Low savings imply a low level of capital accumulation. A low level of capital accumulation implies that productivity stagnates at a low level leading to low income. Therefore, poor countries are trapped in a vicious circle of poverty that can be broken only by exogenous interventions. When foreign aid is channelled into such a country, it would raise incomes above subsistence. The initial savings would increase investment, which would in turn generate further savings in the aid recipient country. 
The two-gap theory, on the other hand, states that investment effort in poor countries in the early stages of development is limited by two constraints. First, due to poverty, these countries are unable to save sufficiently from current income to provide the investment needed to achieve a target rate of economic growth. Second, investment and output are limited by the unavailability of sufficient amounts of imported inputs due to a foreign exchange constraint. The shortage of both domestic savings and foreign exchange to pay for imported materials could be overcome by an inflow of foreign aid. By providing additional resources, economic growth would also rise as the realized incremental investment raises domestic output through higher productive capacity as well as the multiplier effect in the case of underutilized capacity. This has been advanced as one of the most powerful arguments in favour of foreign aid to developing countries.

However, other studies such as Carkovic and Levine [6] have suggested that foreign aid does not exert a robust, independent influence on domestic savings. According to these studies, foreign aid discourages domestic saving through aid-switching; increasing consumption expenditure and reducing efforts to collect taxes. Earlier, Haavelmo [17] indicated that domestic savings in developing countries were directly related not only to the level of GDP but to capital inflows as well. The study concluded that domestic savings in the recipient countries could be negative if capital inflows were large enough. This was taken to imply that foreign capital inflow did not necessarily supplement domestic investment. The latter findings were confirmed by several subsequent studies testing the Haavelmo hypothesis [1, 35]. Rahman [35] verifies Haavelmo's hypothesis showing that domestic savings is not a function of income alone but also has an inverse relationship with the inflow of foreign capital.

The empirical studies undertaken to determine the impact of foreign aid inflow on domestic savings in different countries have also given mixed results. While some studies have found that foreign aid inflow supplemented domestic savings $[2,3,9,16,27]$, other studies found that foreign aid inflow had crowded out domestic savings [5, 17]. Some studies also found that there had been a feedback relationship between the two variables [4, 24, 29, 37]. Yet, other studies have indicated that the two variables are, in fact, independent [12].

Earlier, the linkage between foreign aid inflow and domestic savings was highlighted by Chung et al. [9] who supported the view that foreign aid raises domestic savings. Later, Gruben and Mcleod [16] using data from 18 Asian and Latin America countries showed that an increase in the share of foreign aid to GDP is positively and significantly related to domestic savings. When absorptive capacity is high, foreign aid does have the expected positive relationship with productivity and saving. For Taiwan, China, Cheung and Lin [8] found that foreign aid had been associated with higher productivity and saving in foreign owned firms and with a spill over to domestically owned firms. A 1 per cent increase in foreign aid was found to be associated with an increase in the productivity of domestic firms and increase in domestic savings in the sector of 1.40 to 1.88 percent.

Shahbaz et al. [38] also found that foreign aid and domestic savings were complementary in case of Pakistan. Muawiya [27] suggested that foreign aid may directly affect economic growth through capital accumulation by bridging the gap between desired investments and domestic savings. A study by Angmortey and Tandoh-Offin [2] established that foreign aid had a positive and significant effect on real domestic savings in Ghana in the long-run. However, the short-run dynamic model revealed that foreign aid had no significant effect on real domestic savings in Ghana in the short-run. Foreign aid did not therefore displace domestic savings both in the short-run and the long-run.

However, other studies undertaken on the impact of foreign aid on domestic savings have found contrary results. For example, Biswajit [5] examines the impact of foreign aid on domestic savings-investment behaviour by looking at the experience of 16 developing countries which had attracted the largest flows of foreign aid in the developing world. The results obtained show that for most countries in the sample, foreign aid flows were not accompanied by any significant changes in the savings and investment rates in the host countries. This implies that foreign aid would have a limited role in raising the growth potential of the recipient countries. The lack of significant relationship between foreign aid and domestic saving and investment could be influenced by the relatively small share of the former in the investments undertaken by the sample countries. Findings from this study suggest that in countries like Singapore and Mexico, there may have been a crowding out of domestic saving. Thus, instead of complementing domestic saving efforts, foreign aid may well be acting as a substitute to the local efforts at promoting savings.

In another study, Katircioglu and Naraliyeva [24] found short term bidirectional causality between foreign aid and domestic savings in the Kazakhstan economy. Bashier and Bataineh [4] investigated the relationship between foreign aid and domestic savings in Jordan and found cointegration between both variables. Similarly, Salahuddin et al. [37] examined the causal relationship between foreign aid and domestic savings in Bangladesh by using the Johansen cointegration and error correction modeling and found a bidirectional relationship between the two variables.

\section{Methodology and Data Analysis}

\subsection{Theoretical Framework}

The two gap model postulated by Chenery and Strout [7] offers a theoretical justification on the provision of foreign aid to developing countries. The model considers the effect of foreign aid on broader macroeconomic variables in explaining how economic growth can be achieved. Even though it supports Harrod-Domar inferences, its departure is on the argument that apart from inadequate domestic savings, 
investment in developing countries is limited by lack of foreign exchange earnings required for the importation of capital goods. Hence, foreign aid is provided to fill the two gaps; investment-savings gap and the foreign exchange gap.

The difference between the required investment and available amount of domestic savings yields the investmentsavings gap defined in equations (1) and (2);

$$
\begin{aligned}
& I-S_{d}=\mathrm{FA} \\
& I=S_{d}+F A
\end{aligned}
$$

Where $I$ stands for required investment, $S_{d}$ is domestic savings, $F A$ is the amount of foreign aid and $I-S_{d}$ is the investment-savings gap. The size of this gap provides an indication on the amount of foreign aid inflow required to finance the investment. In this case, the shortfall in required investment is financed by foreign aid inflow.

The two gap model also recognizes that developing countries are relatively less endowed with capital goods which have to be imported [32]. Countries are encouraged to generate enough export earnings for importing the required capital goods. However, efforts to generate these earnings are hampered by low prices fetched on international markets as most export goods from these countries are agricultural based. The shortfall in export earnings is complemented by foreign resources to close the foreign exchange gap shown by using the trade balance in equation (3).

$$
X-M=F A
$$

Where $X$ and $M$ are total exports and imports respectively. Foreign aid in this case ensures that the economy has raised enough resources to purchase the required capital for investment.

This study borrowed Outtara Bazoumana [31] model which is an extension of Morisset [26] model by taking into account factors that determine the capacity to save (GDP growth) and factors that determine the willingness to save (inflation and interest rate). In addition to these variables, foreign direct investment and exports were also included. This yields the following specification for the determinants of domestic savings:

$$
\mathrm{SAV}=\mathrm{f}(\mathrm{AID}, \mathrm{GDP}, \mathrm{INF}, \mathrm{FDI}, \mathrm{INT}, \mathrm{EXP})
$$

Where, $S A V$ is gross domestic savings as a ratio of GDP, $A I D$ is foreign aid inflows as a ratio of GDP, GDP is annual growth rate of GDP, INF is inflation rate, $F D I$ is foreign direct investment to GDP ratio, INT is interest rate and EXP is exports as a ratio of GDP.

$$
S A V Y_{t}=\beta_{0}+\beta_{1} A I D Y_{t}+\beta_{2} G D P Y_{t}+\beta_{3} I N F Y_{t}+\beta_{4} F D I Y_{t}+\beta_{5} I N T Y_{t}+\beta_{6} E X P Y_{t}+\mu_{t}
$$

From equation (5), $S A V Y_{t}$ is the gross domestic savings in the current period as a ratio of GDP, $A I D Y_{t}$ is the foreign aid inflows in the current period as a ratio of GDP, $G D P Y_{t}$ is the annual growth rate of GDP, $I N F Y_{t}$ is the inflation rate, $F D I Y_{t}$ is foreign
Equation (4) shows that potentially, domestic savings is determined by foreign aid inflow, gross domestic product, inflation, foreign direct investment, interest rate and exports. The a priori impact of foreign aid as envisaged in the two gap model is expected to be positive since aid supplements domestic savings and foreign exchange shortages.

Edwards [12] suggests additional variables to explain the behaviour of domestic savings. These variables include: the currency-to-GDP ratio, per capita GDP, population age and private-sector credit. To include these variables would improve the model's fit but lead to a loss in terms of degrees of freedom. The empirical model was, therefore, restricted to the variables mentioned earlier, making it as parsimonious as possible.

\subsection{The Model}

Most macroeconomic time-series exhibit a non-stationary pattern and, therefore, the empirical analysis requires certain prior diagnostic tests to be carried out [28]. Unit root tests were performed to investigate the stationarity of the series. Many unit root tests are proposed in the literature. In this study however, we used two tests, namely Augmented Dickey-Fuller test [10] and Phillips-Perron test [33]. If the series are found to be non-stationary, a cointegration test is performed to find out whether a linear combination of these series converges to an equilibrium. Johansen and Juselius's [23] cointegration method was used in this study. The Johansen and Juselius's techniques require pre-testing for unit root in the variables and are valid if variables are I(1). Also Utkulu [43] argued that cointegration analysis allows non-stationary data to be used so that spurious results are avoided.

Engle and Granger [13] provided a firm theoretical base for representation, testing, estimating and modelling of cointegrated non-stationary time-series variables. They introduced the methods for estimating the long-run equation and the short-run error-correction model. The economic theory relating to the long-run equilibrium relationship between variables and short-run adjustment (disequilibrium) behaviour is considered. This study employed an error-correction model adopted from Mahua and Sakthivel [25] and Sobhan and Islam [39] to analyse both the short-run and long-run effects of foreign aid inflow on domestic savings, but with some modifications. The empirical specification of the savings model to be estimated is, therefore, assumed to take the following functional form: direct investment to GDP ratio, $I N T Y_{t}$ is the interest rate, $E X P Y_{t}$ is exports as a ratio of GDP, and $\mu_{t}$ is the error term.

Using equation (5), the long-run dynamic equation can then be derived. This is expressed as equation (6):

$$
S A V Y_{t}=\gamma_{0}+\gamma_{1} \Delta A I D Y_{t}+\gamma_{2} \Delta G D P Y_{t}+\gamma_{3} \Delta I N F Y_{t}+\gamma_{4} \Delta F D I Y_{t}+\gamma_{5} \Delta I N T Y_{t}+\gamma_{6} \Delta E X P Y_{t}+\gamma_{7} E C T Y_{t-1}+S A V Y_{t-1}+\varepsilon_{t}
$$


From equation (6), ECT is the error-correction term that captures the divergence from the long-run equilibrium. It reflects attempts to correct deviations from the long-run equilibrium and its coefficient represents the rate of adjustment. Most macroeconomic time-series are subject to some type of trend and therefore data is differenced until stationary is achieved.

\subsection{Data Types and Sources}

The study used time-series data for the period 19702016. Data on gross domestic savings, foreign aid inflows, the annual growth rate of GDP, foreign direct investment and exports were obtained from the World Development Indicators databases of the World Bank [44]. Data on inflation and interest rate were obtained from Uganda Bureau of Statistics 2014, 2015 and 2016 Statistical Abstracts [41]. In this study, gross domestic saving is the sum of private and public savings, and is expressed in US dollars.

\section{Empirical Results and Discussion}

\subsection{Diagnostic Tests}

\subsubsection{Unit-root Tests}

Unit-root tests were applied to the model's series to determine whether or not they follow a stationary stochastic process. Table 1 shows the results of both the Augmented Dickey-Fuller test and the Phillips-Perron test. The Augmented Dickey-Fuller test is for the null hypothesis $\left(H_{0}\right)$ that the tested variable has a unitroot (non-stationary). For the level series, the calculated $t$ statistic is not greater than the critical value; hence we cannot reject the null hypothesis of the series being non-stationary at the 1 percent significance level. Therefore, the series can be differentiated as many times as necessary, and the unit-root test can be used to tell when it becomes stationary, thereby finding its order of integration. Table 1 also shows the results of the Augmented Dickey-Fuller test for the series' first difference. The $t$-statistic found enables us to reject the null hypothesis, indicating that the series are stationary at first-difference.

Table 1. Unit Root tests.

\begin{tabular}{|c|c|c|c|c|c|c|}
\hline \multirow{3}{*}{ Variable } & \multicolumn{3}{|c|}{ Augmented Dickey-Fuller test } & \multicolumn{3}{|c|}{ Phillips-Perron test } \\
\hline & \multicolumn{2}{|c|}{ T-Statistic } & \multirow{2}{*}{ Critical values } & \multicolumn{2}{|c|}{ T-Statistic } & \multirow{2}{*}{ Critical values } \\
\hline & Level & Difference & & Level & Difference & \\
\hline AID & -1.675 & -5.532 & $-3.610(1 \%)$ & -1.850 & -5.563 & $-3.610(1 \%)$ \\
\hline GDP & -1.475 & -4.420 & $-3.610(1 \%)$ & -1.075 & -4.430 & $-3.610(1 \%)$ \\
\hline INF & -1.733 & -5.050 & $-3.610(1 \%)$ & -1.983 & -4.962 & $-3.610(1 \%)$ \\
\hline FDI & -1.122 & -7.464 & $-3.610(1 \%)$ & -0.825 & -9.635 & $-3.610(1 \%)$ \\
\hline INT & -1.312 & -8.684 & $-3.610(1 \%)$ & -1.316 & -8.435 & $-3.610(1 \%)$ \\
\hline $\mathrm{SAV}_{-1}$ & -2.684 & -5.268 & $-3.610(1 \%)$ & -2.618 & -6.437 & $-3.610(1 \%)$ \\
\hline
\end{tabular}

Source: Author's computations and all tests run with constant and intercept

These results were confirmed by the Phillips-Perron test whose null hypothesis was that the variable has a unit root. The Phillips-Perron unit root test differs from the Augmented Dickey-Fuller test mainly on how it deals with serial correlation and heteroskedasticity in the errors. One advantage of the Phillips-Perron test over the Augmented Dickey-Fuller test is that it is robust to general forms of heteroskedasticity in the error term. Secondly, the user does not have to specify a lag length for the test. The PhillipsPerron test confirms the non-rejection of the null hypothesis that the tested series have a level unit-root and are firstdifference stationary variables. Thus, the Phillips-Perron test agrees on all variables with the Augmented Dickey-Fuller test as indicated in Table 1.

\subsubsection{Structural Break Test}

To find whether significant changes exist in the relation between the series over the period of the study, structural break tests were applied to the series. The CUSUM square test was conducted based on the accumulated sum of recursive residuals to detect the variable's instability. The test results shown in Figure 1 indicate instability of the estimated model in 1997. The CUSUM was found to exceed the 5 percent significance critical line in 1997 suggesting the presence of a structural break in this period.

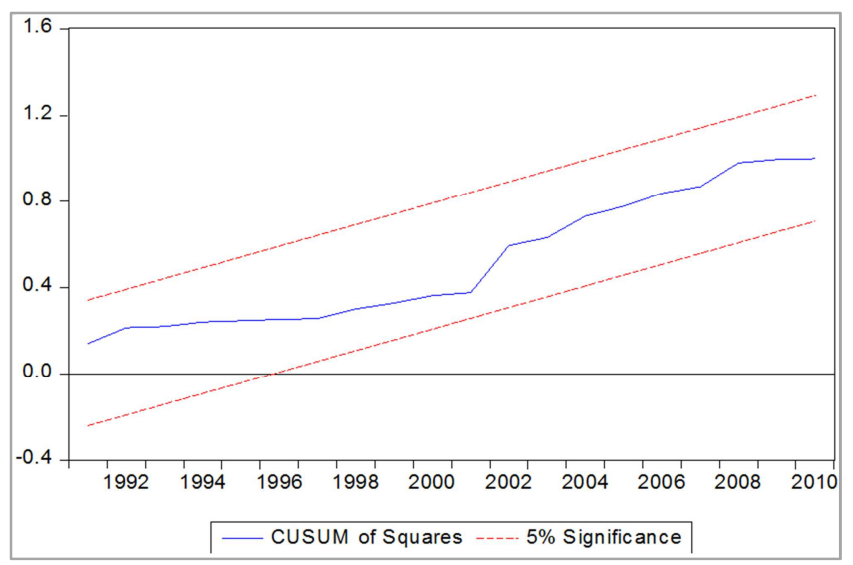

Figure 1. CUSUM Square Test.

Based on the results of the CUSUM, the Chow Test was conducted to test whether the date of the observed break is significant. Results in Table 2 show a rejection of the Chow test's null hypothesis of absence of structural break, pointing out 
a structural break in the period indicated by the previous test.

Table 2. Chow Breakpoint Test: 1997.

Null Hypothesis: No breaks at specified breakpoints

\begin{tabular}{lll}
\hline Statistics & Value & Probability \\
\hline F-statistic & 2.751 & 0.056 \\
Maximum likelihood ratio & 20.249 & 0.002 \\
\hline
\end{tabular}

Source: Author's Computations

\subsubsection{Cointegration Tests}

Since the variables under consideration were found to be non-stationary and become stationary in their first difference, a cointegration test was performed to find out whether a linear combination of these series converges to an equilibrium or not. Johansen and Juselius's [23] cointegration method was used in this study. An appropriate lag length was chosen and the results are indicated in Table 3. Through identification of restrictions, structural economic relationships are explained by the long-run model. Impulse Response Analysis was employed to trace out the time paths of various shocks in the variables contained in the Vector Autoregressive (VAR). To do this, the VAR was reformulated into a vector moving average. Impulse response analysis was used to describe the chain reaction or knock-on effects arising from one standard shock in one innovation in the system over time on all the variables in the system, assuming no other shocks hit the system thereafter. Both orthogonalized and generalized impulse responses were used for this purpose.

Table 3. VAR Lag Order Selection Criteria.

Endogenous variables: SAV AID GDP INF FDI INT EXP

\begin{tabular}{lllllll}
\hline Lag & LogL & LR & FPE & AIC & HQ \\
\hline 0 & -1036.252 & NA & $7.30 \mathrm{e}+15$ & 56.391 & 56.696 \\
1 & -857.242 & 280.609 & $6.80 \mathrm{e}+12$ & 49.364 & 51.802 \\
2 & -805.158 & 61.937 & $7.75 \mathrm{e}+12$ & 49.197 & 53.769 & 50.224 \\
3 & -687.191 & $95.648^{*}$ & $4.66 \mathrm{e}+11$ & 45.469 & 50.809 & 52.174 \\
4 & -556.495 & 56.517 & $7.11 \mathrm{e}+10^{*}$ & $41.053^{*}$ & $49.892^{*}$ \\
\hline
\end{tabular}

* indicates lag order selected by the criterion

LR: Sequential Modified LR Test Statistic (each test at 5\% level)

FPE: Final Prediction Error

AIC: Akaike Information Criterion

SC: Schwarz Information Criterion

HQ: Hannan-Quinn Information Criterion

The variables were linearized by taking their logs since the VAR does not capture non-linear elements and the variables have exponential growth especially those related to investment. The lag length of three was the optimal choice, after considering the selection criteria based on $\log$ likelihood. A log-estimation of different lag lengths and choice by the Schwarz Criterion (SC) and the Akaike Information Criterion (AIC) led to the conclusion that a VAR with four lags would be optimal.

The presence of cointegration however, implies that a stationary long-run relationship among the series is present. If variables are considered to be I(1), the cointegration method is appropriate to estimate the long run relationship. The concept of cointegration is that non-stationary time series are cointegrated if a linear combination of these variables is stationary. The cointegration requires the error term in the long-run relation to be stationary.

The study adopted the approach of analysing multivariate cointegrated systems developed and expanded by Johansen and Juselius [23]. The Johansen Vector Autoregressive (VAR) procedure allows the simultaneous evaluation of multiple relationships and imposes no prior restrictions on the cointegration space. The Johansen cointegration approach tests for the cointegration rank for a VAR process, estimates the TRACE and LMAX statistics, eigenvalues and eigenvectors respectively. It computes the long-run equilibrium coefficients, the adjustment coefficients, the covariance matrix of the errors, and the R-squares for each of the equations. In addition, it also tests for linear restriction on the long-run equilibrium coefficients. To reject or accept the null hypothesis, the computed F statistic is compared with the critical values. If the long-run relationship is confirmed, the autoregressive distributed lag (ARDL) approach is used to estimate the dynamic structure of the structural equations using the ordinary least squares (OLS) method.

Table 4. Unrestricted Cointegration Rank Test (Trace).

\begin{tabular}{lllll}
\hline Hypothesized & & Trace & $\mathbf{0 . 0 5}$ & \\
\hline No. of CE(s) & Eigenvalue & Statistic & $\begin{array}{l}\text { Critical } \\
\text { Value }\end{array}$ & Prob.** \\
\hline None * & 0.937 & 282.832 & 125.615 & 0.000 \\
At most 1 * & 0.867 & 177.333 & 95.753 & 0.000 \\
At most 2* & 0.653 & 100.489 & 69.818 & 0.000 \\
At most 3* & 0.499 & 60.267 & 47.856 & 0.002 \\
At most 4* & 0.492 & 33.989 & 29.797 & 0.015 \\
At most 5 & 0.181 & 8.190 & 15.494 & 0.445 \\
At most 6 & 0.014 & 0.572 & 3.841 & 0.449 \\
\hline
\end{tabular}

Trace test indicates 5 cointegrating equations at the 0.05 level

* Denotes rejection of the hypothesis at the 0.05 level

**MacKinnon-Haug-Michelis (1999) P-values

According to Johansen [22], if the values calculated by the $\lambda$ trace and $\lambda$ maximo statistics exceed the respective critical values, we reject the null hypothesis of non-cointegration in favour of the alternative hypothesis of one or more 
cointegrating vectors being present. The tests' values can be seen in Tables 4 and 5. At the 5 percent significance level, the null hypothesis of non-cointegration is rejected. When the trace statistic or the maximum eigenvalue is compared with the 5 per cent critical value and the trace statistic/maximum eigenvalue is higher than the critical value, then we have the co-integrating equations.

Table 5. Unrestricted Cointegration Rank Test (Maximum Eigenvalue).

\begin{tabular}{lllll}
\hline Hypothesized & & Max-Eigen & $\mathbf{0 . 0 5}$ & \\
\hline No. of CE(s) & Eigenvalue & Statistic & $\begin{array}{l}\text { Critical } \\
\text { Value }\end{array}$ & Prob.** \\
\hline None * & 0.937 & 105.498 & 46.231 & 0.000 \\
At most 1 & 0.867 & 76.844 & 40.077 & 0.000 \\
At most 2 & 0.653 & 40.221 & 33.876 & 0.007 \\
At most 3* & 0.499 & 26.278 & 27.584 & 0.072 \\
At most 4 & 0.492 & 25.798 & 21.131 & 0.010 \\
At most 5 & 0.181 & 7.617 & 14.264 & 0.419 \\
At most 6 & 0.014 & 0.572 & 3.841 & 0.449 \\
\hline
\end{tabular}

Max-eigenvalue test indicates 3 cointegrating equations at the 0.05 level

* denotes rejection of the hypothesis at the 0.05 level

**MacKinnon-Haug-Michelis (1999) P-values

The trace and maximum auto value statistics indicate the presence of at most five cointegrated vectors, suggesting that the model's non-stationary variables show common paths, so that there is at least one stable relation between them in the long-run. This supports the conclusion that the five variables included in the model display a long-term equilibrium relation.

\subsubsection{Autocorrelation Coefficient of Residuals}

The stationarity of residuals $\left(\mathrm{ECT}_{\mathrm{t}}\right)$ obtained from equation (6) is based on autocorrelation coefficients and Q-statistics. In the case of small sample, examination of autocorrelation function should be an important criterion according to Hall [18]. It is apparent from Table 6 that all the autocorrelation coefficients $(p k)$ lie within the confidence interval of $[-0.364$, $0.364]$ up to the 16th lag. Hence, the hypothesis that the true $p k$ is zero is not rejected. Similarly, to test the joint hypothesis that all $p k$ autocorrelation coefficients are simultaneously equal to zero, the Q-statistic is used.

Table 6. Autocorrelation Coefficient of Residuals.

\begin{tabular}{lll}
\hline Lags & AC & Q-Stat \\
\hline 1 & 0.331 & 4.824 \\
2 & 0.197 & 6.572 \\
3 & 0.066 & 6.774 \\
4 & 0.064 & 6.970 \\
5 & -0.01 & 6.979 \\
6 & -0.09 & 7.414 \\
7 & -0.07 & 7.688 \\
8 & -0.22 & 10.189 \\
9 & -0.16 & 11.56 \\
10 & -0.33 & 21.97 \\
11 & -0.1 & 22.559 \\
12 & -0.07 & 22.879 \\
13 & -0.02 & 22.914 \\
14 & -0.07 & 23.268 \\
15 & 0.033 & 23.34 \\
16 & 0.023 & 23.377 \\
\hline
\end{tabular}

This provides a basis to conclude that the residuals from cointegrating regression appear to be stationary which in turn, suggests a valid long-run relationship among variables. This relationship is further shown by the cointegration test results in Table 7 .

Table 7. Results of the Cointegration Test.

\begin{tabular}{lll}
\hline Variable & t-ADF & Lag lengths \\
\hline Residual & $-4.869 * * *$ & 1 \\
\hline $\begin{array}{l}\text { Note. Critical value at } 10 \%=-2.607,5 \%=-2.937 \text { and } 1 \%=-3.605 . * * * \\
\text { Indicate significance at } 1 \% .\end{array}$
\end{tabular}

\subsection{Estimation Results and Discussion}

\subsubsection{Short-run Dynamic Error Correction Model}

Given that $S A V, A I D, G D P, I N F, F D I, I N T$ and EXP are cointegrated, the error-correction model was estimated to determine the short-run dynamics of the system. The results from the residual-based approach give strong evidence that the variables are indeed cointegrated, thus justifying the use of the error-correction model. Three models; E1, E2 and E3 were constructed and E3 was selected because there was no serial correlation as indicated in Table 8 .

Table 8. Parsimonious Short-run Gross Domestic Savings Model.

\begin{tabular}{llll}
\hline Regressors & E1 & E2 & E3 \\
\hline C & -2.041 & -1.982 & $-1.841^{*}$ \\
D(AIDY) & $-0.456^{* *}$ & $-0.430^{* *}$ & $-0.441^{* * *}$ \\
ECT(-1) & $-0.453^{* *}$ & $-0.523^{* *}$ & $-0.614^{* * *}$ \\
SAVY(-1) & $0.958^{* * *}$ & $0.990^{* * *}$ & $1.011^{* * *}$ \\
D(GDPY(-2)) & $0.041^{* * *}$ & $0.046^{* * *}$ & $0.039 * *$ \\
D(INF(-2)) & $-0.050^{* * *}$ & $-0.048^{* * *}$ & $-0.045^{* * *}$ \\
D(AIDY(-1)) & -0.116 & & \\
D(AIDY(-2)) & $0.437 * *$ & $0.453^{* * *}$ & $0.418^{* * *}$ \\
D(INF) & 0.020 & 0.018 & \\
D(GDPY(-1)) & -0.020 & -0.012 & $0.153 * *$ \\
INT & $0.193 *$ & $0.164 *$ & \\
D(FDIY(-1)) & -0.721 & -0.491 & \\
INT(-1) & 0.094 & 0.073 & \\
INT(-2) & 0.039 & & -0.004 \\
D(FDIY) & -0.808 & -0.647 & \\
D(EXP) & -0.009 & -0.007 & 0.635 \\
D(EXP(-2)) & -0.004 & & \\
D(FDIY(-2)) & -0.377 & -0.246 & 2.386 \\
R-squared & 0.871 & Mean dependent var & 6.077 \\
Adjusted R-squared & 0.761 & S.D. dependent var & 4.406 \\
F-statistic & 7.920 & Durbin-Watson stat & 2.386 \\
Prob (F-statistic) & 0.000 & & \\
Diagnostic Tests & & & \\
Serial Correlation & $32 * * *$ & $28.2 *$ & \\
Heteroscedasticity & 21.8 & 10.95 & \\
Normality & 3.947 & 3.24 & \\
\hline
\end{tabular}

Note. $* * *, * *, *$ indicates significance at $1 \%, 5 \%$ and $10 \%$ respectively and ECT is the Error Correction Term computed from equation (6).

Using the concept of General-to-Specific modelling, the 2 lag of both explanatory and dependent variables and 1 lag of residual $\left(\mathrm{ECT}_{\mathrm{t}}\right)$ from cointegrating regression were included to get a parsimonious model. This involved the inclusion of the lagged residuals obtained from the long-run regression. The Error-Correction Term (ECT) in the short-run estimation of gross domestic savings model was obtained from the 
general error-correction model. The coefficients of foreign aid inflow were found to be negative implying that foreign aid has a negative impact on domestic savings in Uganda.

The model shows a negative coefficient of the errorcorrection term and is statistically significant at 1 per cent. It also indicates that the system corrects its previous period's level of disequilibrium by 44 per cent within a year. The results show again that the explanatory variables explain the level of gross domestic savings in Uganda in the short-run. The R-squared value is 0.87 , indicating that about 87 percent of the variation in domestic savings in Uganda in the shortrun is determined by the explanatory variables. The reported Durbin-Watson is 2.38 suggesting the absence of autocorrelation. The diagnostic tests both the general and parsimonious short-run gross domestic savings results show they have passed all the tests.

\subsubsection{Long-run Model}

Using the long-run model, we shall also construct an errorcorrection term, which is used together with stationary variables in cointegrating relationships, to construct the error correction model which integrates short-run and long-run dynamics of the model. The coefficients of the error correction term should be negative and significant if the disequilibrium is to be corrected in the subsequent period and the long-run equilibrium restored. The coefficient represents the speed of adjustment to the long-run equilibrium. Analysis of the long-run model shows the estimated parameters for SAVY, AIDY, GDPY, INF, FDIY, INT and EXP presented in Table 9.

Table 9. Long-Run Model.

Dependent Variable: SAVY

Sample: 19702016

Included observations: 47

\begin{tabular}{lllll}
\hline Variable & Coefficient & Std. Error & t-statistic & Prob. \\
\hline C & 12.808 & 2.170 & 5.902 & 0.000 \\
AIDY & -0.708 & 0.149 & -4.759 & 0.000 \\
GDPY & 0.004 & 0.009 & -0.480 & 0.035 \\
INF & 0.029 & 0.018 & -1.574 & 0.025 \\
FDIY & 0.488 & 0.611 & 0.799 & 0.030 \\
INT & -0.024 & 0.154 & -0.157 & 0.876 \\
EXP & 0.003 & 0.002 & 1.523 & 0.037 \\
ECT_1 & -0.501 & 0.1566 & -3.442 & 0.000 \\
R-Squared & 0.572 & Mean dependent variable & 6.692 \\
Adjusted R- & 0.496 & S.D. dependent variable & 4.819 \\
Squared & & \multicolumn{4}{|l}{ Hannan-Quinn Criteria } & 5.558 \\
Log likelihood & -104.761 & Durbin-Watson Statistic & 1.169 \\
F. Statistic & 7.563 & & \\
Prob (F-Statistic) & 0.000 & &
\end{tabular}

The long-run saving model is given in the equation (7).

$$
S A V Y=12.808-0.708 A I D Y+0.004 G D P Y+0.029 I N F+0.488 F D I Y-0.024 I N T+0.003 E X P
$$

Results in equation (7) show that, in the long-run, foreign aid has a negative impact on domestic savings in Uganda. An increase in foreign aid inflow by 1 percent of GDP leads to 0.71 percent decrease in gross domestic savings in the longrun. This implies that in the long run, foreign aid inflow crowds-out domestic savings in Uganda. These research findings are consistent with some of the preceding studies elsewhere showing that foreign aid has a negative effect on domestic savings [14, 34]. According to Griffin [14], the negative and significant aid coefficient suggests that some aid switching was taking place. Radelet [34] even argued that foreign aid is detrimental to domestic savings in recipient nations because it results in disincentives to save.

The impact of growth in GDP on domestic savings was found to be positive and significant. A 1 percent increase in the growth of GDP leads to 0.004 percent increase in domestic savings. These results show support for the lifecycle hypothesis of saving. According to the life-cycle hypothesis, savings ratio tends to rise with a rise in the rate of growth of income because the higher the growth rate, the higher the gap between the target consumption levels of the current generation of working household and the dissaving of retired people from a less prosperous generation. Thus, countries with higher growth rates might be expected to have at least higher personal savings ratios than countries with lower growth rates. This confirms results by Dzogbenu [11], Hussein and Thirlwall [19] and Quattara [31].

The impact of the rate of inflation on domestic savings was also found to be positive and significant. A 1 percent increase in inflation rate leads to 0.029 percent increase in domestic savings. Inflation acts as a tax on money balance holdings. If individuals wish to restore the real value of their money balance holdings (the real balance effect), saving will rise with the rate of inflation. This also assumes that the reduction in public savings is more than offset by the increase in private sector savings.

The impact of exports on domestic savings is positive but mild. This could be due to the fact that exports of goods and services in Uganda mainly comprise of agricultural products such as coffee and tea which have been subject to falling terms of trade over time. Furthermore general instability in prices and export volumes during the period of study could be responsible for the dismal influence of exports.

The impact of foreign direct investment on domestic savings is positive and significant. A 1 percent increase in Foreign Direct Investment results in an increase of 0.49 percent in gross domestic savings. However, interest rates exert a negative and insignificant impact on domestic savings in the long- run.

\section{Conclusion and Policy Implications}

\subsection{Conclusion}

This study set out to determine the effect of foreign aid inflow on domestic savings in Uganda. The study was motivated by the low savings ratio which has been identified as one of the major constraints to future growth in Uganda, under Vision 2025. 
Error-Correction Modelling was applied on a time series database for the period 1970-2016. Unit-root tests were applied to the model's series to determine whether or not they follow a stationary stochastic process. The variables were found to be non-stationary and became stationary in their first difference. A cointegration test was performed to find out whether a linear combination of these series converges to an equilibrium or not using Johansen and Juselius's cointegration method. Structural Break Test was applied to the series to find whether significant changes exist in the relation between the series over the period of the study.

Results of the study show that foreign aid has a negative impact on domestic savings in Uganda both in the short-run and the long-run. An increase in foreign aid inflow by $1 \%$ of GDP leads to $0.71 \%$ decrease in gross domestic savings in the long-run. This implies that in the long run, foreign aid inflow crowds out domestic savings in Uganda. In this study, the findings support the substitution hypothesis that foreign aid inflow substitutes domestic saving. One explanation, which has attracted some attention, is that by making resources easily available, external flows encourage a relaxation in saving effort and support an increase in consumption and therefore, external flows may particularly impede the domestic saving efforts.

The study also found out that the growth in GDP, inflation and exports had a positive impact on domestic savings in Uganda.

\subsection{Policy Recommendations}

The study suggests that foreign aid has a negative impact on domestic savings in Uganda in the long-run. A policy implication of this result is that Uganda should be wary in soliciting for foreign aid. If foreign aids become expedient, then it should be channeled to productive ventures.

The results of the study indicate that growth in GDP influences domestic savings in Uganda positively and significantly. This finding suggests that the government should implement policies directed towards improvement in people's income and creation of employment opportunities. Government policies should focus on ways of increasing GDP in Uganda in order to increase domestic savings in the country.

The study also suggests that foreign direct investment has a positive impact on domestic savings in Uganda. Therefore, policy makers need to create a favorable environment to attract foreign direct investments.

\section{References}

[1] Ahmed, N. (1971). A note on the Haavelmo hypothesis. Review of Economics and Statistics 53, 413-414.

[2] Angmortey B. N. and Tandoh-Offin P. (2014): Does Foreign Capital Crowd-Out Domestic Saving in Developing Countries? An Empirical Investigation of Ghana, International Journal of Economics and Finance; Vol. 6, No. 8; 2014 ISSN

\section{6-971X E-ISSN 1916-9728.}

[3] Baharumshah, A. Z., and Thanoon, H. (2000): Foreign Capital, Savings and Economic Growth: A dynamic Panel Study on the East Asian Countries. Department of Economics. University of Putra. Malaysia.

[4] Bashier, A. and Bataineh, T. (2007). The casual relationship between foreign direct investment and saving in Jordan, International Management Review 3 (4): 12-18.

[5] Biswajit, M (2018): Macroeconomic Impact of Public debt and foreign aid in Sri Lanka. Journal of Policy Modeling, Elsevier, vol 41 (2), pages 372-394.

[6] Carkovic, M. V. and Levine, R. (2002). Does foreign direct investment accelerate economic growth? University of Minnesota, Department of Finance Working Paper.

[7] Chenery, H. and A. Strout (1966): Foreign assistance and economic development. American Economic Review 56.

[8] Cheung, K. and P. Lin (2003) 'Spillover Effects of FDI on Innovation in China: Evidence from the Provincial Data', China Economic Review 15 (1): 25-44.

[9] Chung, C., Chang, L., Zhang, Y., (1995). "The Role of Foreign Direct Investment in China's Post-1978 Development", World Development, 23 (4), pp, 691-707.

[10] Dickey, D. A. and Fuller, W. A.(1979). 'Distributions of the estimators for autoregressive time series with a unit root', Journal of the American Statistical Association, 74, 427-431.

[11] Dzogbenu V. K (1996) "Foreign Aid Inflows and its Implication for Domestic Savings in Ghana" M. A. Thesis, University of Ghana Legon.

[12] Edwards, S., (1995), Why are Saving Rates so Different across Countries? An International Comparative Analysis, NBER Working Papers, (5097).

[13] Engle Robert F. and C. W. J. Granger (1987): Co-Integration and Error Correction, Representation, Estimation, and Testing. Econometrica, Vol. 55, No. 2. pp. 251-276.

[14] Griffin, K. (1970). Foreign capital, domestic savings and economic development. Oxford Bulletin of Economics and Statistics, 55, 99-112. http://dx.doi.org/10.1111/j.14680084.1970.mp32002002.x

[15] Griffin, K. and J. Enos (1970): Foreign Assistance: Objectives and Consequences, Economic Development and Cultural Change, Vol. 18 economy. Cambridge MA, MIT.

[16] Gruben, W. C., \& Mcleod, D. (1998). Capital Flows, Savings and Growth in the 1990s. Quarterly Review of Economics and Finance, 3 (38), 287-301. http://dx.doi.org/10.1016/S10629769(99)80119-7.

[17] Haavelmo, T. (1963): The Econometric Approach to Development Planning. North HollandPublishing Company. Holland.

[18] Hall, P. (1986), "On the bootstrap and confidence intervals", The Annals of Statistics, 14, 1431-1452.

[19] Hussein, K. and A. P. Thirlwall (1999): Explaining Differences in the Domestic Savings RatioAcross Countries: A Panel Data Study. Journal of Development Studies, 36: 3152 . 
[20] IMF Working Paper (2015): Poverty, Growth, and Inequality in Sub-Saharan Africa: Did the Walk Match the Talk under the PRSP Approach? By Daouda Sembene. WP/15/122.

[21] Janicki, H. P. and Wunnava, P. V (2004): Determinants of Foreign Direct Investment: Empirical Evidence from EU Accession Candidates. Applied Economics, 36 (5): 505-509.

[22] Johansen, S. (1988), 'Statistical Analysis of Cointegrating Vectors, Journal of EconomicDynamics and Control, 12: 231254.

[23] Johansen, S. and Juselius, K. (1994):'Testing Structural Hypothesis in a Multivariate Cointegration Analysis of the PPP for UK, Journal of Econometrics, 53: 211-244.

[24] Katircioglu, S. T., Naraliyeva, A. (2006). Foreign Direct Investment, Domestic Savings and Economic Growth in Kazakhstan: Evidence from Co-Integration and Causality Tests, Investment Management and Financial Innovations, Vol. 3, Issue 2.

[25] Mahua, R., \& Sakthivel, E. (2000). Has Foreign Savings 'Crowded-out' Domestic Savings in India? An Empirical Investigation. Institute of Economic Growth. University of Delhi Enclave, North Campus. Delhi.

[26] Morisset, J. (1989), "The Impact of Foreign Capital Inflows on Domestic Savings Reexamined: The Case of Argentina'. World Development 17 (11): 1709-15.

[27] Muawiya A. H. (2009): "Impacts of Foreign Direct Investment on Economic Growth in Gulf Cooperation Council (GCC) countries", International Review of Business Research Papers, 5 (3), pp. 362-376.

[28] Nelson, C. R. and Plosser, C. I. (1982). 'Trends and random walks in macroeconomic time series', Journal of Monetary Economics 10, 139-162.

[29] Odhiambo, N. M. (2009). Savings and Economic Growth in South Africa: A Multivariate Causality Test. Journal of Policy Modelling, 31, 708-718.

[30] Osundina J. A., \& Osundina, C. K. (2014). Interest rate as a link to investment decision in Nigeria. Journal of Economics and Finance, 2 (4), 08-14.

[31] Ouattara, B. (2006): "Foreign aid and government fiscal behavior in developing countries: Panel data evidence," Economic Modeling, vol. 23, p. 506-514.

[32] Ozekhome, H. O. (2017). "Foreign Aid, Foreign Direct Investment And Economic Growth In Ecowas Countries: Are There Diminishing Returns In The Aid-Growth Nexus?" West
African Journal of Monetary and Economic Integration, West African Monetary Institute, vol. 17 (1).

[33] Phillips, P. C. B. and Perron, P. (1988). 'Testing for a unit root in a time series regression', Biometrika 75, 335-346.

[34] Radelet, S. (2006). “A Primer on Foreign Aid," Center for Global Development, Working Paper No. 92, July.

[35] Rahaman, M. A. (1968): Foreign Capital and Domestic Savings. A Test of Haavelmo's Hypothesis with CrossCountry Data. Review of Economic Statistics, 50 (February), 137-138. http://dx.doi.org/10.2307/1927068

[36] Rostow, W. W. (1960): The Stages of Economic Growth. A non-communist Manifesto. Cambridge University Press, Cambridge.

[37] Salahuddin, M., Shahbaz, M. and Chani, M. I. (2010). A Note on Causal Relationship between FDI and Savings in Bangladesh, Theoretical and Applied Economics, 11, 53-62.

[38] Shahbaz M., R. U. Awan and L. Ali, (2008). "Bi-Directional Causality between FDI and Saving: A Case Study of Pakistan," International Research Journal of Finance and Economic, No. 17, pp. 75-83.

[39] Sobhan, and Islam (1988) Foreign Aid and Domestic Resource Mobilization in Bangladesh. Bangladesh Development Studies 26.

[40] Taslim, J. T., and Weliwita, R. (2000): Foreign Direct Investment and Productivity: Evidence from Selected Countries. In Building Coalitions for Effective Development Finance. Global Development Finance.

[41] Uganda Bureau of Statistics 2014, 2015 and 2016 Statistical Abstracts.

[42] Uneze, E. (2011). Testing the Impact of Foreign Aid and Aid Uncertainty on Private Investment in West Africa, Centre for Study of Economies of Africa, CSEA Working Paper WP/11/01, February.

[43] Utkulu, U. (1994): Cointegration Analysis: Introductory Survey with Applications to Turkey, in M. Güneş, Ş. Üçdoğruk and M. V. Pazarlıoglu (eds) (Papers at the International Symposium of Econometrics and Statistics), 303-24, İzmir.

[44] World Bank (2017): National accounts data at http://data.worldbank.org viewed on $2^{\text {nd }}$ April 2017.

[45] World Bank, (2018). World Development Indicators database, Washington, DC. 